Letters

\title{
Electrodeposition of Zn-Mg Alloy from Trimethyl Propylammonium Bis (trifluoromethylsulfonyl) imide Ionic Liquid
}

\author{
Hiroaki YAMAMOTO*, Hironobu KINOSHITA**, \\ Hiroshi SHIRAI*, Masao MORISHITA* and Koichiro KOYAMA* \\ ${ }^{*}$ Graduate School of Engineering, University of Hyogo(2167, Shosha, Himeji-shi, Hyogo 671-2201) \\ ${ }^{* *}$ Graduate School of Engineering, University of Hyogo [presently] Sumikin Kikoh Co.,Ltd. (Fuso-cho, \\ Amagasaki-shi, Hyogo 660-0891)
}

\begin{abstract}
Keywords : Trimethyl Propylammonium Bis(trifluoromethylsulfonyl)imide, Electrodeposition, Zinc-Magnesium Alloy, Ethylene Glycol, Ionic Liquid
\end{abstract}

\section{Introduction}

We have studied about the electrodeposition of $\mathrm{Zn}-\mathrm{Mg}$ alloy, which shows very high corrosion resistance, from the baths using 1-ethyl-3-methylimidazolium bromide (EMIB) ionic liquid ${ }^{1 \sim 4)}$. In order to obtain basic metal, Mg, with $\mathrm{Zn}$, the EMIB based baths must be dehydrated thoroughly, and the constant potential electrodepositions must be conducted at near the potential where the reduction of $\mathrm{EMI}^{+}$ cation occurred $^{1) 33}$. Constant current electrodeposition at high current density causes the reduction of $\mathrm{EMI}^{+}$cation. Trimethyl propylammonium bis (trifluoromethylsulfonyl)imide (TMPATFSI) is one of the ionic liquids which have wide electrochemical potential windows and hydrophobic property ${ }^{5) \sim 8)}$. This TMPATFSI appears to be preferable to EMIB for the electrodeposition of $\mathrm{Zn}-\mathrm{Mg}$ alloy. We have already reported about the electrodeposition of $\mathrm{Zn}$ from TMPATFSI based bath as a previous step to $\mathrm{Zn}-\mathrm{Mg}$ alloy electrodeposition ${ }^{9)}$. In this paper, the electrodeposition of $\mathrm{Zn}-\mathrm{Mg}$ alloy from the bath using TMPATFSI was investigated.

\section{Experimental}

We previously reported about the electrodeposition of $\mathrm{Zn}-\mathrm{Mg}$ alloy from ethylene glycol (EG) added EMIB baths ${ }^{1)}$ or glycerin (G) added EMIB baths ${ }^{3)}$. $\mathrm{Mg}$ contents in the electrodeposits obtained from EG-added baths were $0.3-2.5 \mathrm{~mol} \%$ and those obtained from G-added baths were $0.48-25 \mathrm{~mol} \%$ ). The addition of $\mathrm{G}$ seems to be effective for $\mathrm{Zn}-\mathrm{Mg}$ alloy electrodeposition. However, $\mathrm{Zn}-\mathrm{Mg}$ alloy plated steel containing more than $2.5 \mathrm{~mol} \% \mathrm{Mg}$ showed high corrosion resistance independently of $\mathrm{Mg}$ content and $\mathrm{Zn}-\mathrm{Mg}$ alloy plating containing more than $20 \mathrm{~mol} \% \mathrm{Mg}$ obtained from G-added baths had a tendency to have a lot of cracks and peel off from the substrate. Thus, the electrodeposition of $\mathrm{Zn}^{9)}$ and $\mathrm{Zn}-\mathrm{Mg}$ alloy from EG-added TMPATFSI baths were investigated. $\mathrm{Zn}$ $(\mathrm{TFSI})_{2}$ (Sanko Chemical Industry Co., water $\leqq 0$.
1\%) was dehydrated under vacuum at $373 \mathrm{~K}$ for $72 \mathrm{~h}$ before use. $\mathrm{Zn}(\mathrm{TFSI})_{2}$, EG (Kanto Chemical Co., purity $>99.5 \%$, water $\leqq 0.2 \%$ ), and TMPATFSI (Sanko Chemical Industry Co., water $\leqq 0.2 \%$ ) were weighed in the composition of TMPATFSI-Zn (TFSI $)_{2}$-EG $(48: 12: 40 \mathrm{~mol} \%)$ and mixed. This mixture was dehydrated under vacuum again to prepare the $\mathrm{Zn}$ plating bath. $\mathrm{Mg}$ ion was introduced into the bath by anodic dissolution under constant current density of $50 \mathrm{Am}^{-2}$ at $393 \mathrm{~K}$ using a copper cathode (purity: $99.99 \%, \quad 0.3^{\mathrm{t}} \mathrm{mm} \times 30 \mathrm{~mm} \times 5 \mathrm{~mm}$ ) electropolised in orthophosphoric acid and a magnesium anode (purity: 99.97\%, $0.3^{\mathrm{t}} \mathrm{mm} \times 30 \mathrm{~mm} \times 5$ $\mathrm{mm}$ ) degreased by acetone. These substrates were exchanged every passed charge of $50 \mathrm{C}$. Concentration of $\mathrm{Mg}$ ion and $\mathrm{Zn}$ ion in the bath was measured by ICP analysis (Seiko Instruments Inc., SPS-4000) to calculate the composition of the bath. The electrodeposition of $\mathrm{Zn}-\mathrm{Mg}$ alloy was conducted on the copper substrate in TMPATFSI- $(\mathrm{Zn}, \mathrm{Mg})(\mathrm{TFSI})_{2}$-EG (48: $(12-x: x): 40 \mathrm{~mol} \%)$ bath under constant current density of $50 \mathrm{Am}^{-2}$ for $2.5 \times 10^{5} \mathrm{Cm}^{-2}$ at $393 \mathrm{~K}$. After washing with acetone and water, and drying, the electrodeposits were examined by XRD (Rigaku, RINT-2200) and EPMA (JEOL, JXA-8900 R). Preparation of bath and electrodeposition were conducted in Ar gas filled glove box (MIWA MFG, DB 0-1-W).

\section{Results and discussion}

The electrodeposition of $\mathrm{Zn}-\mathrm{Mg}$ alloy was conducted in the TMPATFSI- $\left(\mathrm{Zn}, \mathrm{Mg}\right.$ ) (TFSI) ${ }_{2}$-EG (48: (6: 6) : $40 \mathrm{~mol} \%$ ) bath under constant current density of $50 \mathrm{Am}^{-2}$ for $2.5 \times 10^{5} \mathrm{Cm}^{-2}$ at $393 \mathrm{~K}$. The obtained electrodeposit was analyzed by XRD and the result is shown in Fig. 1 (a). XRD peaks corresponding to the $\mathrm{Cu}$ substrate, $\mathrm{Zn}$, and $\mathrm{CuZn}_{5}$, which was considered to be formed between the $\mathrm{Cu}$ substrate and the $\mathrm{Zn}$ deposit, were detected. In addition, the weak peaks suggesting the deposition of $\mathrm{Zn}-\mathrm{Mg}$ alloy, $\mathrm{Mg}_{2} \mathrm{Zn}_{11}$, were observed in Fig. 1 (a). Since the XRD peaks of $\mathrm{Mg}_{2} \mathrm{Zn}_{11}$ was very weak, the component elements of 
the electrodeposit were analyzed by EPMA to confirm the co-electrodeposition of $\mathrm{Mg}$. Figure 2 shows the SEM image and EPMA mapping images of $\mathrm{Zn}$ and $\mathrm{Mg}$ of the surface of the electrodeposit. This result indicates that the electrodeposit contains $\mathrm{Zn}$ element and $\mathrm{Mg}$ element, and $\mathrm{Mg}$ exists almost uniformly in the electrodeposit. $\mathrm{Mg}$ content in this specimen measured by EPMA quantitative analysis was about 5 mol\%. According to the equilibrium phase diagram of the $\mathrm{Mg}-\mathrm{Zn}$ binary system, $\mathrm{Mg}$ is hardly solidsoluted in $\mathrm{Zn}^{10)}$. From these results, it seems that $\mathrm{Mg}$ in the electrodeposit exists as $\mathrm{Mg}_{2} \mathrm{Zn}_{11}$ and/or supersaturated solid solution in $\mathrm{Zn}$ in nonequilibrium state. In order to verify the state of $\mathrm{Mg}$ in the electrodeposit, the electrodeposition of $\mathrm{Zn}-\mathrm{Mg}$ alloy under the same condition as mentioned above was conducted on the W substrate so as not to form intermetallic compound between the substrate and the electrodeposit, and it was heat-treated at $573 \mathrm{~K}$ for $10.8 \mathrm{ks}$. Figure 1 (b) and (c) show the XRD patterns of the electrodeposit on the $\mathrm{W}$ substrate before and after heat treatment, respectively. The XRD pattern of Fig. 1 (b) is almost the same as Fig. 1 (a). The lattice constant ( $\AA$ ) of $\mathrm{Zn}$ in $\mathrm{Zn}-\mathrm{Mg}$ alloy electrodeposit calculated from the $\mathrm{XRD}$ peaks at high angles is $(\mathrm{a}, \mathrm{c})=(2.671,4.955)$ whereas that of pure $\mathrm{Zn}$ is $(\mathrm{a}, \mathrm{c})=(2.665,4.947)^{11)}$. It is possible that $\mathrm{Mg}$ is solid-soluted in $\mathrm{Zn}$. As shown in Fig. 1 (c), the XRD peaks corresponding to $\mathrm{Mg}_{2} \mathrm{Zn}_{11}$ are sharpened and much clear after heat treatment. These result suggests the possibility that $\mathrm{Mg}$ exists as supersaturated solid solution in $\mathrm{Zn}$ in the $\mathrm{Zn}-\mathrm{Mg}$

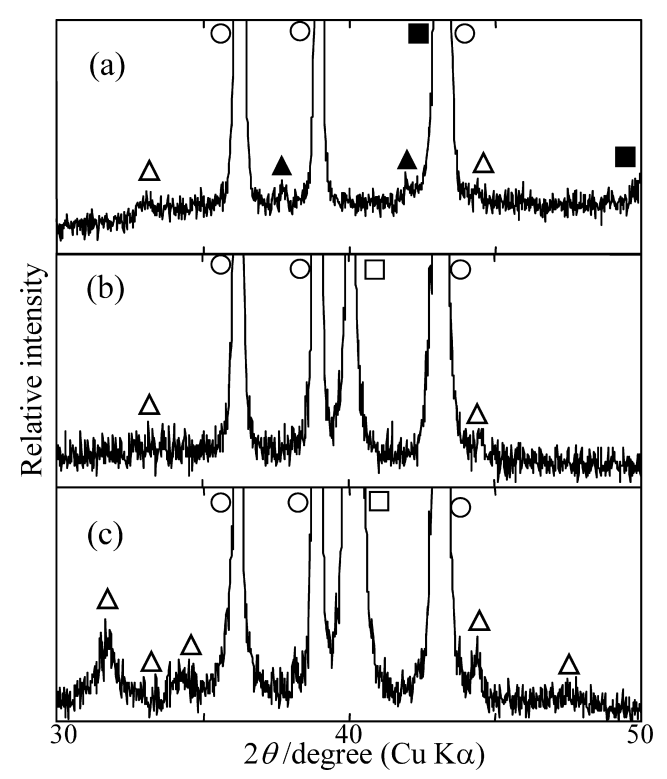

Fig. 1 X-ray diffraction patterns of the electrodeposits obtained from the TMPATFSI- $(\mathrm{Zn}, \mathrm{Mg})(\mathrm{TFSI})_{2}$-EG $(48:(6: 6): 40 \mathrm{~mol} \%)$ bath under the constant current density of $50 \mathrm{Am}^{-2}$ with passed charge of $2.5 \times 10^{5}$ $\mathrm{Cm}^{-2}$ at $393 \mathrm{~K}$ on (a) $\mathrm{Cu}$ and (b, c) W substrate. (c) shows the XRD pattern of the specimen after heat treatment at $573 \mathrm{~K}$ for $10.8 \mathrm{ks}$. $\bigcirc: \mathrm{Zn}, \boldsymbol{\square}: \mathrm{Cu}, \square$ : $\mathrm{W}, \boldsymbol{\Delta}: \mathrm{CuZn}_{5}$, and $\triangle: \mathrm{Mg}_{2} \mathrm{Zn}_{11}$. electrodeposit obtained from the TMPATFSI- $(Z n$, $\mathrm{Mg})(\mathrm{TFSI})_{2}$-EG $(48:(6: 6): 40 \mathrm{~mol} \%)$ bath under constant current density of $50 \mathrm{Am}^{-2}$ for $2.5 \times 10^{5} \mathrm{Cm}^{-2}$ at $393 \mathrm{~K}$.

Figure 3 shows the $\mathrm{Mg}$ contents of the electrodeposits obtained from TMPATFSI- $(\mathrm{Zn}, \mathrm{Mg})(\mathrm{TFSI})_{2}$ EG $(48:(12-\mathrm{x}: \mathrm{x}): 40 \mathrm{~mol} \%)$ baths under constant current density of $50 \mathrm{Am}^{-2}$ for $2.5 \times 10^{5} \mathrm{Cm}^{-2}$ at $393 \mathrm{~K}$. As the concentration of $\mathrm{Mg}$ ion in the bath increased within the limit of $0 \leqq x \leqq 6, M g$ content in the electrodeposit increased. The maximum $\mathrm{Mg}$ content was about $5 \mathrm{~mol} \%$ in the electrodeposit obtained from the TMPATFSI-( $\mathrm{Zn}, \mathrm{Mg})$ (TFSI) ${ }_{2}$-EG (48:(6:6): $40 \mathrm{~mol} \%$ ) bath as mentioned above. The structure of $\mathrm{Zn}-\mathrm{Mg}$ alloy electrodeposit in this study is almost the same as that obtained from EMIB based baths in previous study ${ }^{1,3)}$. We have already reported that the corrosion resistance of $\mathrm{Zn}-\mathrm{Mg}$ alloy plated steel containing more than $2.5 \mathrm{~mol} \%$ of $\mathrm{Mg}$ is about 20 times higher than that of $\mathrm{Zn}$ plated steel in 5 mass $\%$ $\mathrm{NaCl}$ aqueous solution at $308 \mathrm{~K}^{4)}$. Thus $\mathrm{Zn}-5 \mathrm{~mol} \% \mathrm{Mg}$ alloy plating prepared in this study is also expected to show high corrosion resistance.

As mentioned above, the electrodeposition of $\mathrm{Zn}-\mathrm{Mg}$ alloy from EMIB based bath was conducted at near the potential where the reduction of $\mathrm{EMI}^{+}$cation occurred in order to obtain $\mathrm{Zn}-\mathrm{Mg}$ alloy at high current densities ${ }^{1) \sim 3)}$, because $\mathrm{Zn}-\mathrm{Mg}$ alloy whose $\mathrm{Mg}$ was dispersed uniformly in the electrodeposit could not be obtained at low current densities ${ }^{2)}$. However, it was obtained at low current density of $50 \mathrm{Am}^{-2}$ in this study. Further investigation including the electrochemical measurements such as cathodic polarization curves and cyclic voltammograms, the activities of ionic species, and the electrodeposition at high current

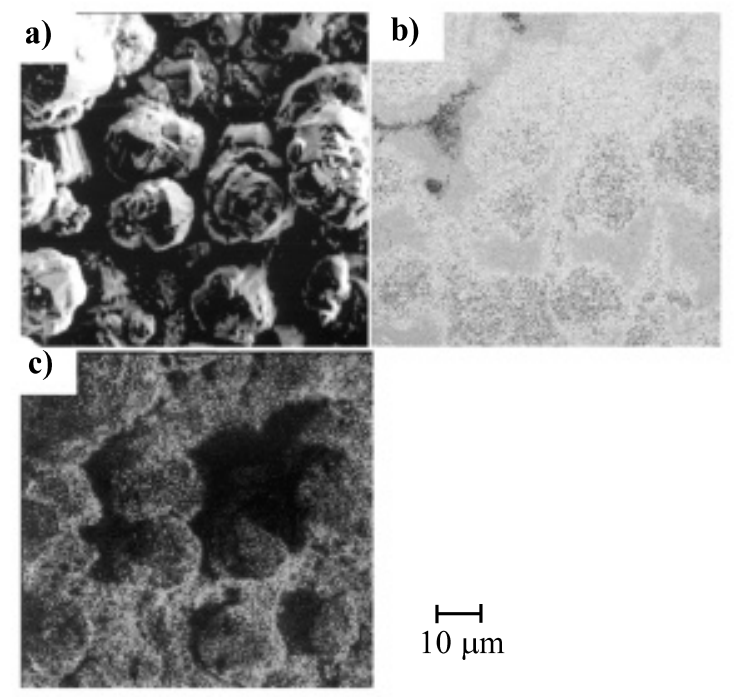

Fig. 2 a) SEM image and EPMA mapping images of b) $\mathrm{Zn}$ and c) $\mathrm{Mg}$ of surface of the electrodeposit obtained from the TMPATFSI- $(\mathrm{Zn}, \mathrm{Mg})$ (TFSI) ${ }_{2}$-EG (48: (6 : 6) : $40 \mathrm{~mol} \%$ ) bath under the constant current density of $50 \mathrm{Am}^{-2}$ with passed charge of $2.5 \times 10^{5} \mathrm{Cm}^{-2}$ at 393 $\mathrm{K}$. 


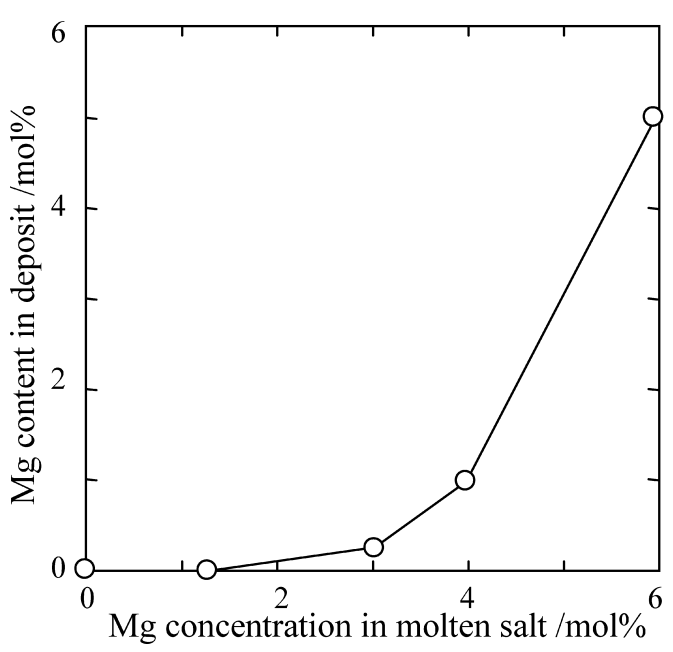

Fig. $3 \mathrm{Mg}$ content in the electrodeposits as a function of $\mathrm{Mg}$ concentration in the TMPATFSI- $(\mathrm{Zn}, \mathrm{Mg})(\mathrm{TFSI})_{2}$ EG $(48:(12-x: x): 40 \mathrm{~mol} \%)$ bath. Electrodeposition was conducted at $50 \mathrm{Am}^{-2}$ with passed charge of $2.5 \times 10^{5} \mathrm{Cm}^{-2}$ at $393 \mathrm{~K}$.

densities in TMPATFSI- $(\mathrm{Zn}, \mathrm{Mg}) \mathrm{TFSI}_{2}$-EG baths are necessary to discuss the effects of structure and properties of TMPATFSI on the electrodeposition of $\mathrm{Zn}$ $\mathrm{Mg}$ alloy.

\section{Conclusions}

The electrodeposition of $\mathrm{Zn}-\mathrm{Mg}$ alloy from the bath using trimethyl propylammonium bis (trifluoromethylsulfonyl)imide (TMPATFSI) was investigated. Zn$\mathrm{Mg}$ alloy containing about $5 \mathrm{~mol} \% \mathrm{Mg}$ was obtained from the TMPATFSI- $(\mathrm{Zn}, \mathrm{Mg})(\mathrm{TFSI})_{2}$-EG (48: $6:$ $6: 40 \mathrm{~mol} \%$ ) bath under the constant current density of $50 \mathrm{Am}^{-2}$ for $2.5 \times 10^{5} \mathrm{Cm}^{-2}$ at $393 \mathrm{~K}$. The electrodeposit consists of $\mathrm{Zn}$ and $\mathrm{Mg}_{2} \mathrm{Zn}_{11}$, and $\mathrm{Mg}$ was electrodeposited as $\operatorname{Mg}_{2} Z_{11}$ and/or supersaturated solid solution in $\mathrm{Zn}$.

（Received March 27, 2006 ; Accepted June 6, 2006）

\section{References}

1) T. Iwagishi, K. Sawada, H. Yamamoto, K. Koyama and H. Shirai ; Electrochemistry, 71, 318 (2003)

2 ) H. Yamamoto, Y. Masuno, H. Shirai and K. Koyama ; Abstracts of the $35^{\text {th }}$ Symposium on Molten salt Chemistry, 35 (2003) 59.

3 ) T. Iwagishi, Y. Nakatsuka, H. Yamamoto, K. Koyama and H. Shirai ; Electrochemistry, 72, 618 (2004)

4 ) H. Yamamoto, Y. Masuno, H. Shirai and K. Koichiro ; J. Surface Finish. Soc. Jpn., 57, 84 (2006)

5 ) H. Matsumoto, T. Matsuda, T. Tsuda, R. Hagiwara, Y. Ito and Y. Miyazaki ; Chem. Lett., 2001, 26.

6 ) D. R. MacFarlane, P. Meakin, J. Sun, N. Amini and M. Forsyth ; J. Phys. Chem. B, 103, 4164 (1999)

7 ) V. R. Koch, L. A. Dominey, C. Nanjundiah and M. J. Ondrechen ; J. Electrochem. Soc., 143, 798 (1997)

8 ) P. Bô 1 nhote, A.-P. Dias, N. Papageorgiou, K. Kalyanasundaram and M. Grätzel ; Inorg. Chem., 35, 1168 (1996)

9 ) H. Yamamoto, H. Kinoshita, M. Kimura, H. Shirai and K. Koyama ; Electrochemistry, 74, 370 (2006)

10) T. B. Massalski ; Binary Alloy Phase Diagrams Second Edition, p. 2572 (ASM International, 1990)

11) L. G. Berry, B. Post, S. Weissmann and W.F. McClune ; Powder Diffraction File Set 1-5, p. 581, \#40831 (Joint Committee on Powder Diffraction Standards, 1974) 